\title{
Studies on mosquitoes (Diptera: Culicidae) and anthropic environment. 3- Survey of adult stages at the rice irrigation system and the emergence of Anopheles albitarsis in South-Eastern, Brazil ${ }^{*}$
}

\author{
Oswaldo Paulo Forattini"*, Iná Kakitani**, Eduardo Massad ${ }^{\star \star \star}$, Daniel Marucci** \\ FORATTINI, O.P. et al. Studies on mosquitoes (Diptera: Culicidae) and anthropic environment. 3- Survey \\ of a adult stages at the irrigation system and the emergence of Anopleles albitarsis in South-Eastern Brazil. \\ Rev. Saúde Pública, 27: 313-25, 1993. A study of adult Culicidae ecology was carried out from January \\ 1992 through January 1993 at the rice irrigation system of the Ribeira Valley Experimental Station. The \\ adaptation of Anopheles albitarsis to the anthropic environment became evident through the adult \\ collections made at its various habitats represented by the irrigation system and the edge of the residual \\ pond, as well as at those made within the local patchy residual woods. Other potential disease vectors were \\ prevalent in the irrigated system too. There were Aedes scapularis, Culex nigripalpus and Cx. ribeirensis \\ that were collected at various habitats. Remarkable differences among their prevalences were obtained such \\ as between the natural forest and anthropic environments. In the former An. albitarsis was practically non- \\ existent, thus suggesting that it might be considered as eusynathropic. As the populations of other species \\ seemed to increase in the anthropic environment, they may be regarded as hemisynanthropes. Observations \\ suggest the hypothesis that the development of irrigated land may be a factor in the emergence of $A n$. \\ albitarsis, and some other species, as well as the possibility of an increase in the transmission of mosquito- \\ borne diseases such as malaria.
}

Keywords: Mosquitoes. Ecology, vectors. Anopheles.

\section{Introduction}

It is fully recognized that agricultural development projects are related to Culicidae production. In several regions of the world, particularly on the Asian and African continents, this association has been studied with regard to large-scale agricultural developments (Lacey and Lacey ${ }^{11}$, 1990). Irrigated ricelands and adults mosquito activities may result in disease problems such as malaria and encephalitis, in addition to pest nuisance. In several parts of North America, the high Psorophora adults production in ricelands has become a serious threat to both human and animal welfare (Robert and Olson ${ }^{18}$, 1986). Regarding South America, the ability of Anopheles darlingi to use rice fields in the malaria endemic regions has already been reported (Giglioli9, 1963). The Jari project, a large agricultural development scheme in the Amazon region, fostered

* Supported by the "Fundação de Amparo à Pesquisa do Estado de São Paulo (FAPESP)" - (Grant n 90/3371-6).

** Department of Epidemiology, School of Public Health, University of S. Paulo. Taxonomic and Systematic Research in Medical Entomology Unit of the University of S. Paulo/ (NUPTEM) - S. Paulo, SP - Brazil.

*** Department of Pathology, School of Medicine, University of S. Paulo.

Reprints: O.P. Forattini - Av. Dr. Arnaldo, 715 -01246-904 - S. Paulo, SP - Brazil.

Edição subvencionada pela FAPESP. Processo Medicina 93/0208-5. conditions conducive to malaria by enlarging the habitat of that vector (McIntyre ${ }^{12}, 1980$ ). Other Neotropical vector species breeding in habitats similar to rice fields can be expected to adapt and to increase their adults density as happens with An. albimanus, an efficient vector in Central America (C. Zozaya cited by Lacey and Lacey ${ }^{11}, 1990$ ).

The Ribeira Valley region of S. Paulo State (Brazil) currently presents malaria and encephalitis prevalences at a hypoendemic level. However, in view of the factors that may contribute to their resurgence, it will be opportune to estimate the impact of agricultural irrigation on the adult mosquito population. As previously mentioned, the implantation of rice cultivation employing the technique of the Experimental Farm in Pariquera-Açu County, provided the opportunity to carry out studies on these matters (Forattini et al. ${ }^{8}$, 1993). Previous observations on adult culicid activities in the same region have been published; without, however, attempting to establish the relationships between mosquito production and the artificial irrigation procedures (Forattini et al ${ }^{3,4,5}, 1981,1986$ ). Concerning that relationship, preliminary data were obtained through adult collection in rice paddies (Forattini et al. ${ }^{6}, 1989$ ). The present paper presents the results of the mosquito faunal survey, comparing populations of the primitive forested habitat with those of the anthropic environment, including the residual patchy woods. The irrigation system is focused mainly as representing a humandeveloped environment available for the adaptation of 
culicid populations. The results relating to adult mosquitoes are presented, as a sequence of the research project, as follows.

\section{Study Area}

Adult collections were performed at the Experimental Station (ES) andFonte (FT) areas that have been described in detail elsewhere (Forattini et al. $.^{78}, 1993$ ). The former represented the rural human settlement with considerable environmental modifications, including the irrigation system (IS). The other site exemplified the original, wild rain forest that characterizes the regional ecosystem. In the ES area the residual wood was represented by two collection sites (A and B) located within the remaining patches of the primitive forest. For a more detailed description of the localization of the collection sites, it is suggested that the reader consult the above-mentioned papers.

\section{Material and Method}

Adult mosquitoes were sampled at fortnightly regular intervals from January 1992 through January 1993. Catches were made from 17:00 to 22:00 hours, which is the period of greatest nocturnal mosquito activity in the study area (Forattini et al. ${ }^{3}, 1981$ ). Shannon type light traps and CDC traps baited with dry ice were used (Fig.1 A to D). A two-man team was used in the Shannon trap, and the collections were performed as follows:

Shan-1 inside residual wood A at ES.

Shan-2 inside residual wood B at ES.

Shan-E in open land at the rice paddy margin at ES.

Shan-3 inside primitive forest at FT.

The Shan- 1 and Shan-2 traps were operated alternately so that the total number of mosquito catches corresponded to the number of fortnightly collections.

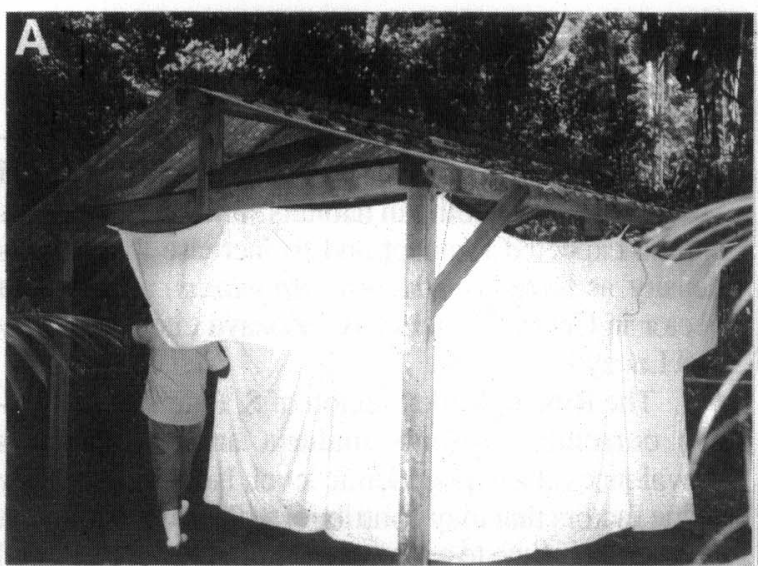

B
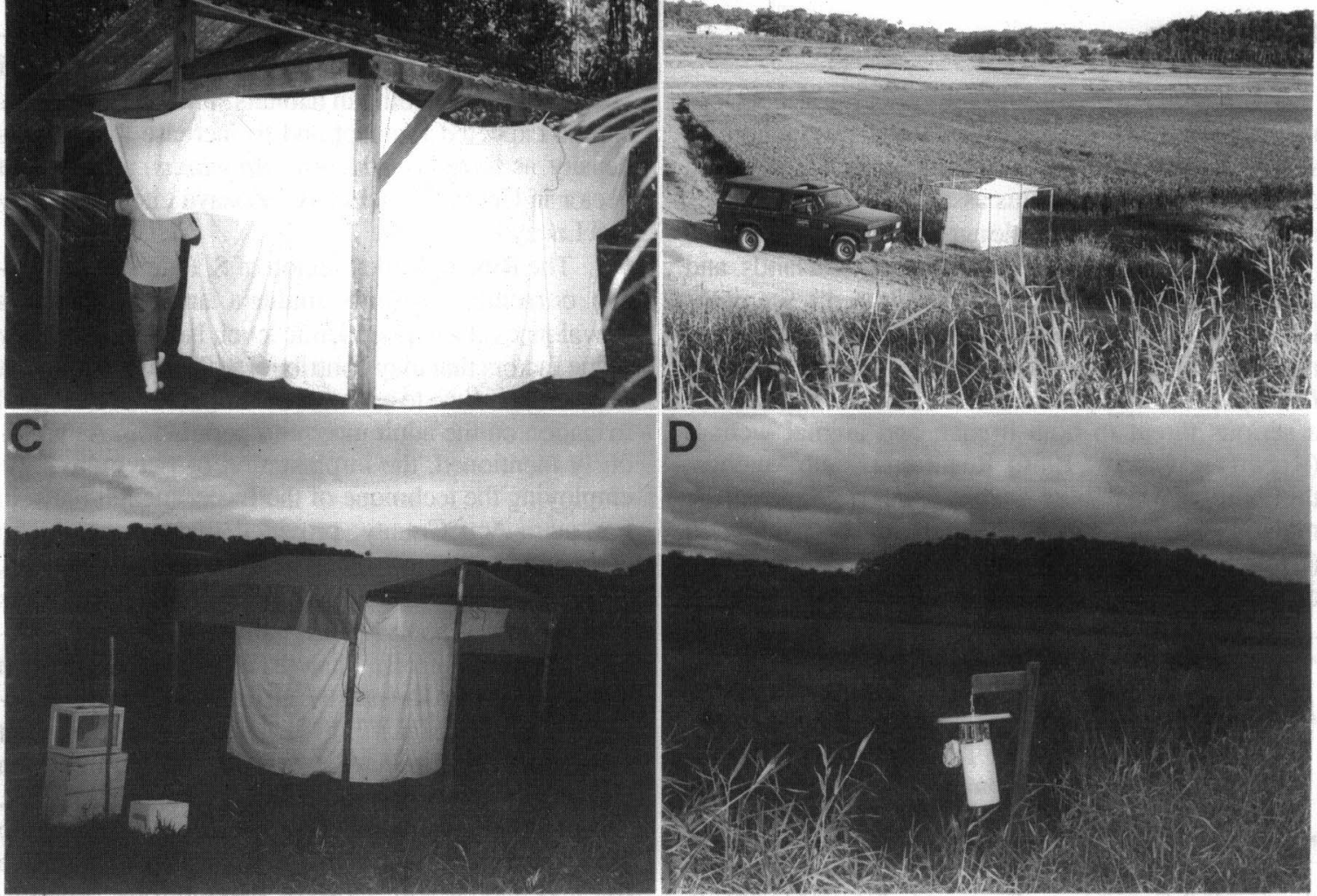

Figure 1. Collection techniques employed. A - Shannon trap operating in the forest environment; B, C - Shannon trap installed in open land environment, near the margin of an irrigated rice field at the Experimental Station (ES); D - CDC automatic trap baited with dry ice. 
The CDC traps operated by the IS and residual pond (RP) at the ES. Each trap was suspended 1 to 1.5 $\mathrm{m}$ above the ground and provided with a cover to protect against rain and the consequent damage to the collected specimens (Fig. 1D). Traps were located as follows:

CDC -1 in the rice paddy (IS).

CDC-2 in the drainage trench (IS).

$\mathrm{CDC}-3$ in the residual pond (RP).

Biodiversity was estimated as proposed by Fisher et al. ${ }^{2}$ (1943), independently of sample size.

Regarding the degree of domiciliation, the synanthropic classification of fliesproposed by Povolny ${ }^{14}$ (1971) was applied. To estimate this, the synanthropic index (s) of Nuorteva ${ }^{13}$ (1963) was calculated for each species, in accordance with the percentages of specimens collected at the different sites, as follows:

$$
s=\frac{2 a+b-2 c}{2}
$$

where:

a- the percentage collected in the anthropic settlement. b- percentage collected in rural surroundings and

c- percentage collected in the wild.

The index ranges from +100 to -100 , the former corresponding to the highest degree of synanthropy or domiciliation. The data recorded were calculated relative to the highest value obtained, which was taken as 1.0 , so the degrees of synanthropy varied from that value down wards.

To undertake the comparisons, ES was considered as the highest feature of anthropic environment (settlement) and so the data of Shan-E were taken as a. The catches made with Shan-1 and Shan-2 corresponded to $\underline{b}$ and the data obtained with Shan-3 toc . To obtain a general over-view of the synanthropy, the ES/ FT ratio between the total numbers of specimens collected at each place was calculated as the synanthropic ratio (sr).

The taxonomic identifications are presented with the generic and subgeneric names abbreviated according to Reinert ${ }^{16,17}(1975,1982)$.

Data about the IS flooding and the general prevailing environmental temperature pattern have been described elsewhere (Forattini et al. ${ }^{8}, 1993$ ) and were obtained from the records of the Oceanographic Institute of the University of S. Paulo ${ }^{10}, 1989$. Heavier rainfall coincides with the warmest period of the year from October to March, the dry and colder season lasting from April to September.

\section{Results}

A total of 90,935 adult mosquitoes $(89,578$ females and 1,357 males) were collected, which include $53,527(58.9 \%)$ from the ES and $37,408(41.1 \%)$ from the FT. The number of identifications made are presented in Tables 1 and 2 . Of that total, $85.9 \%$ were identified to species and $14.1 \%$ as belonging to various taxonomic categories.

\section{Experimental Station (ES)}

Of the total specimens collected, 34,843 females were obtained by the Shannon traps and 17,546 by the CDC traps. Of the species identified, the more prevalent were as follows:

$\begin{array}{lr}\text { Species } & \% \\ \text { Aedes scapularis } & 15.3 \\ \text { Anopheles albitarsis } & 12.1 \\ \text { Culex nigripalpus } & 10.8 \\ \text { Mansonia indubitans } & 8.5 \\ \text { Coquillettidia venezuelensis } & 8.3 \\ \text { Culex ribeirensis } & 7.3 \\ \text { Total } & 62.3\end{array}$

Despite the close proximity of the collection sites to each other, different patterns were observed. The most prevalent species collected on the open land, are shown in Table 3 . The high prevalence of Ae. scapularis and An. albitarsis representing more than $50.0 \%$ of the females caught, is clear. In contrast, in the collections from the RP Ma. indubitans, $C x$. nigripalpus and $C x$, ribeirensis predominated, jointly accounting for more than $60.0 \%$ of the total catch. The percentage of Ae. scapularis and An. albitarsis recorded over the monthly total of mosquito catches at RP is presented in Fig. 2A. An inverse tendency regarding these two species seems to have taken place in this habitat, which represents a permanent breeding place for mosquitoes. Some aspects of the other species are presented in Fig. 2B, where a similar inversion was observed with $C x$. nigripalpus and $C x$. ribeirensis.

The monthly distributions of the female $A e$. scapularis and An. albitarsis captured by Shan-E and CDC-1 plus CDC-2 are shown in Fig. 3. Even when taking into consideration that these species disperse widely when host seeking, the patterns obtained suggest a preference for the flooded IS condition by $A n$. albitarsis, and of the empty IS by Ae. scapularis. This aspect was more evident from the CDC catches made during the seasonal transition period (April and May). This probably happened because these traps sampled mainly newly emerged females in the vicinity of the breeding places. 
Table 1. Adult Culicidae collected by Shannon traps at the Experimental Station (ES) and "Fonte" (FT) from January 1992 through January 1993.

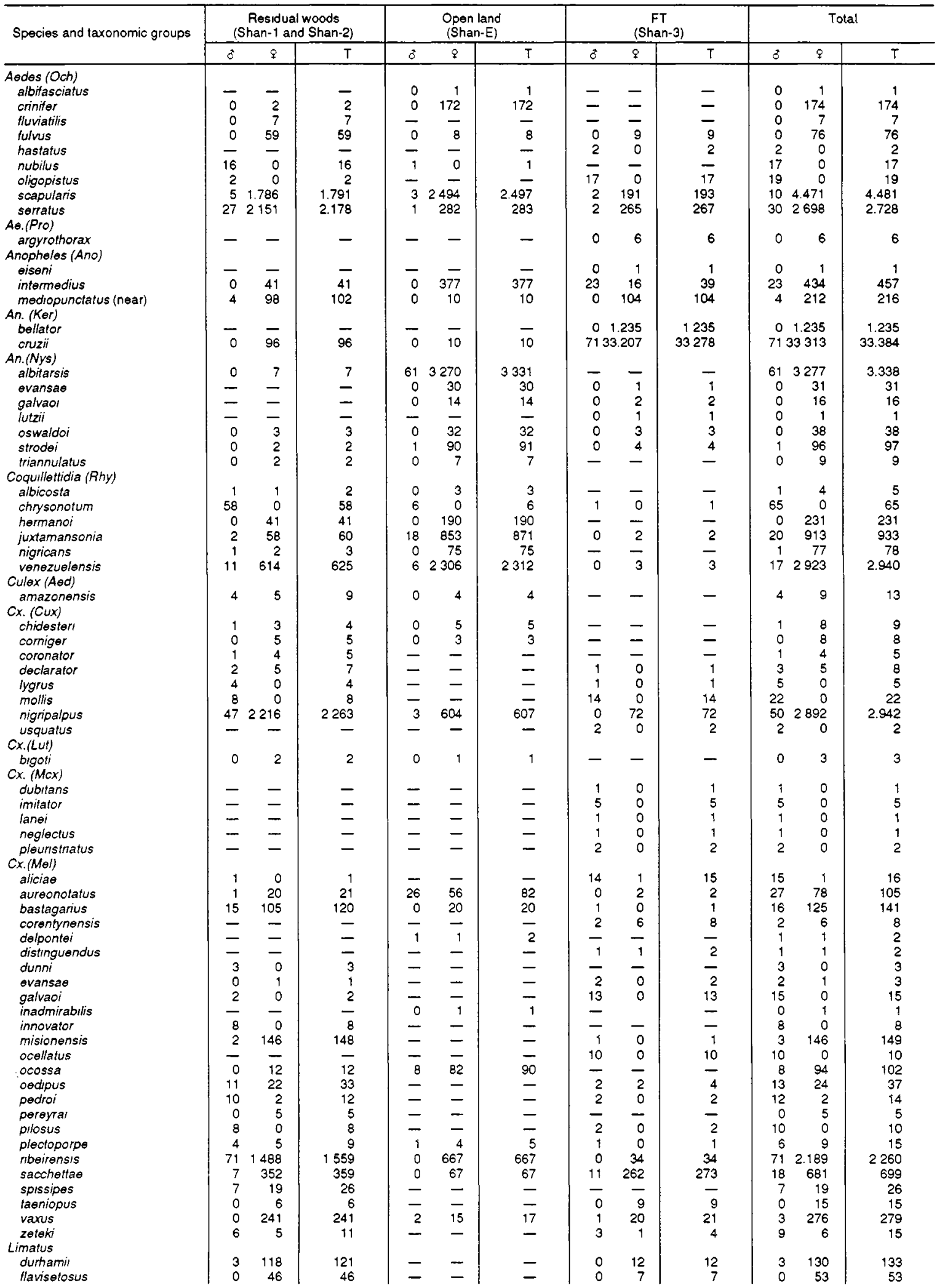




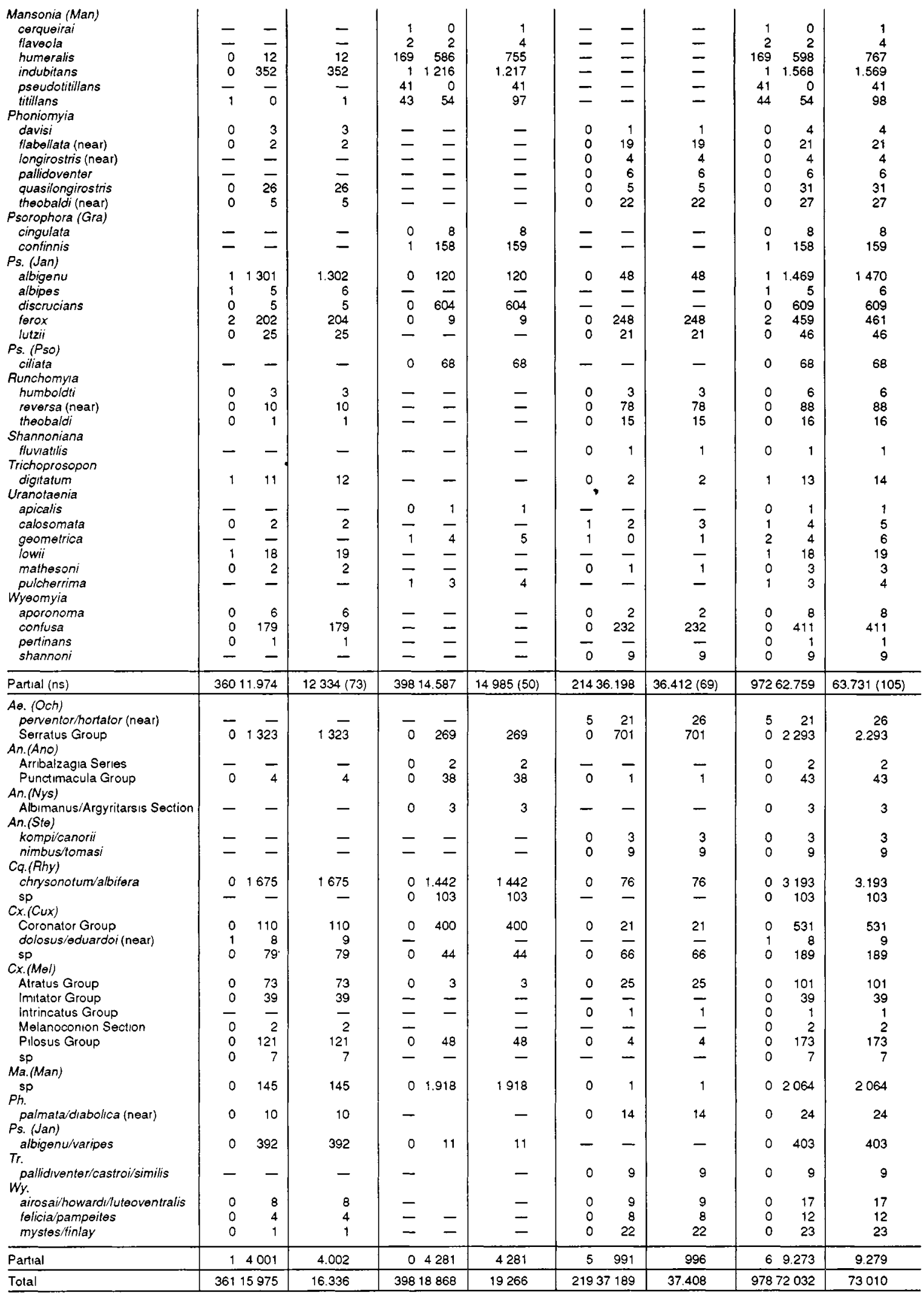

(ns) - Number of species 
Table 2. Adult Culicidae collected by CDC traps at the Experimental Station (ES) from January 1992 through January 1993.

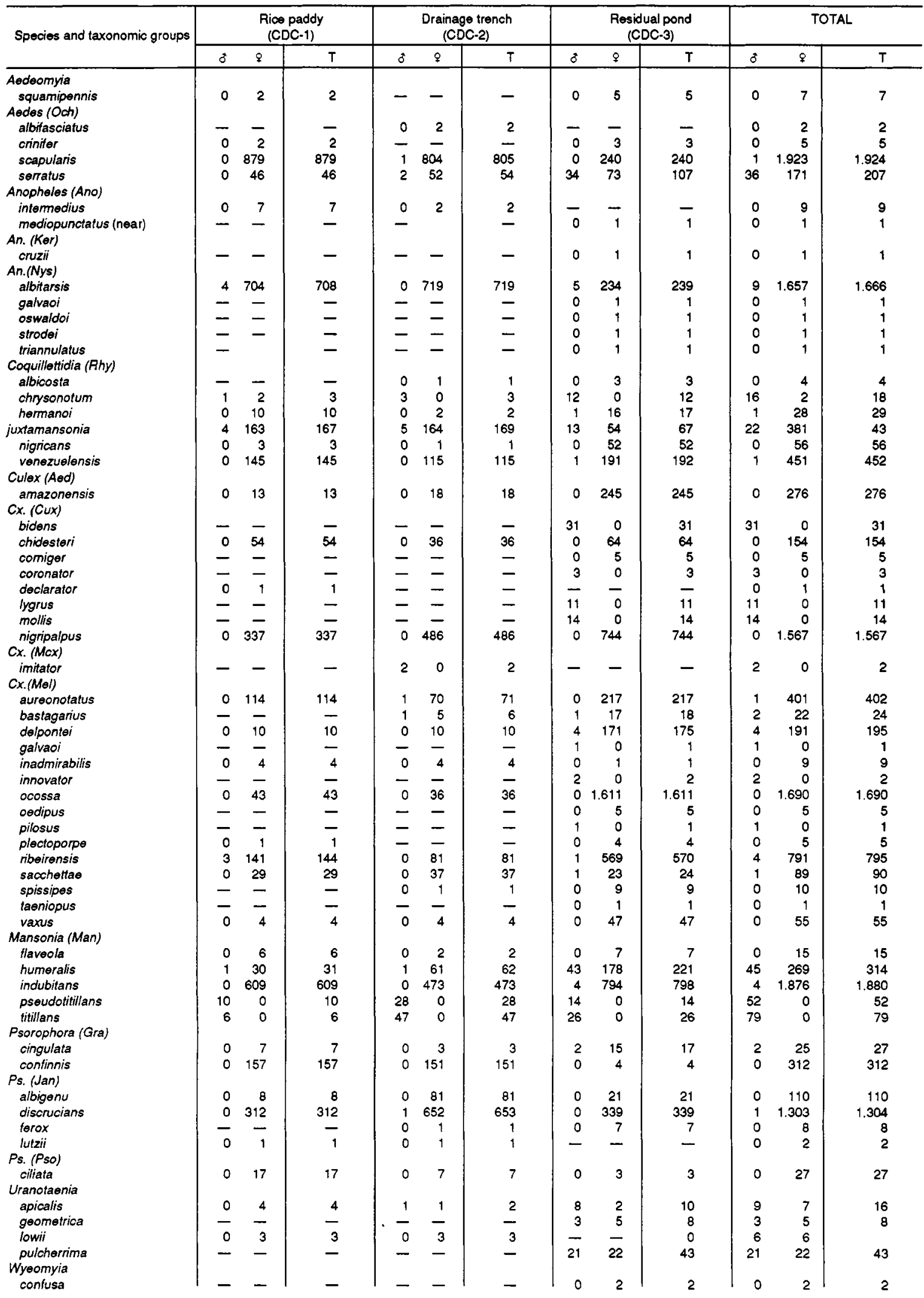




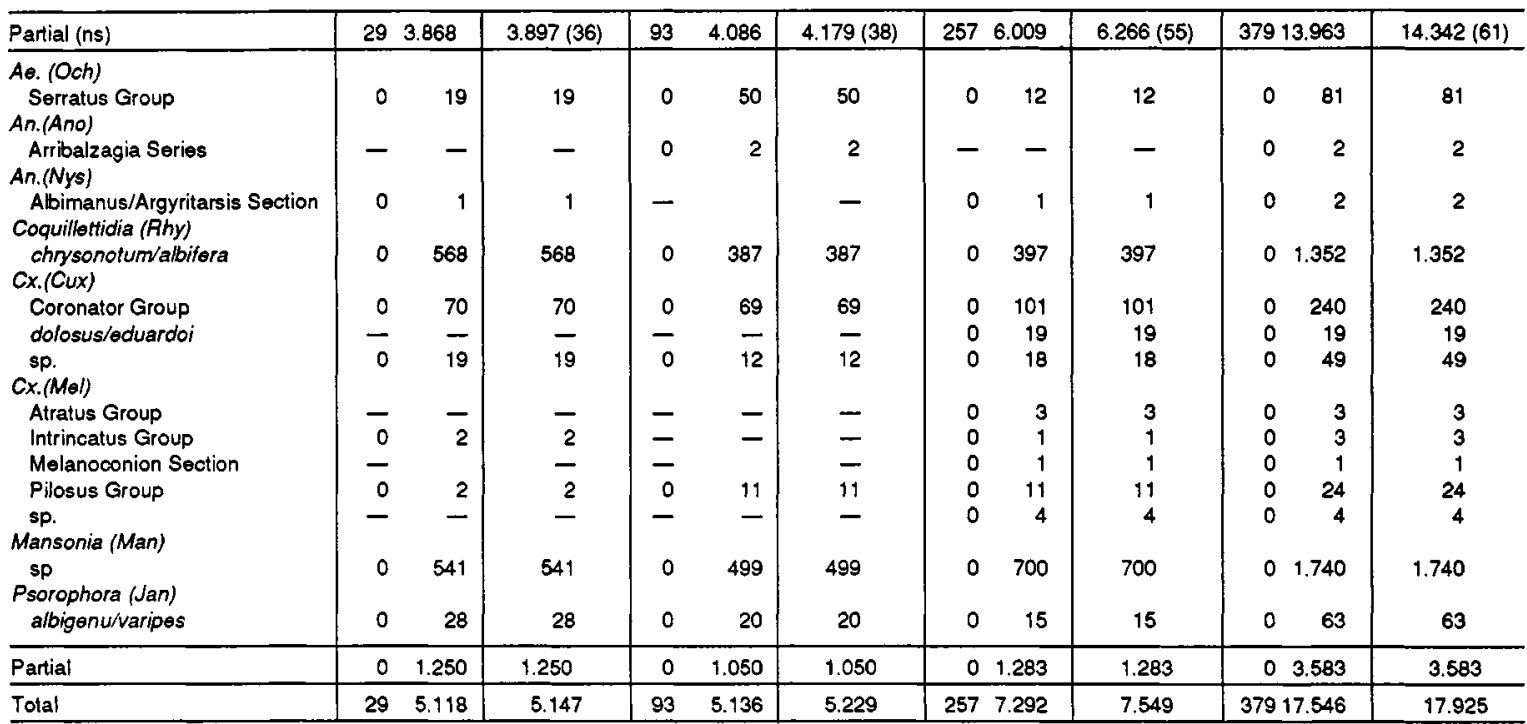

(ns) - Number of species.

Table 3. Collections of the most prevalente Culicidae species (females) at the paddy margin, irrigation system (IS) and residual pond (RP) of the Experimental Station (ES) from January 1992 through January 1993."

\begin{tabular}{|c|c|c|c|c|c|c|c|c|}
\hline \multirow[t]{2}{*}{ Collection Sites } & \multicolumn{2}{|c|}{$\begin{array}{l}\text { Paddy margin } \\
\text { (Shan-E) }\end{array}$} & \multicolumn{2}{|c|}{$\begin{array}{c}1 S \\
(C D C-1+C D C-2)\end{array}$} & \multicolumn{2}{|c|}{$\begin{array}{c}\mathrm{RP} \\
(\mathrm{CDC}-3)\end{array}$} & \multicolumn{2}{|c|}{ TOTAL } \\
\hline & $\mathrm{n}$. & $\%$ & n. & $\%$ & n. & $\%$ & $\mathrm{n}$. & $\%$ \\
\hline Ae. scapularis & 2.494 & 23.6 & 1.683 & 30.5 & 240 & 8.7 & 4.417 & 23.4 \\
\hline An. albitarsis & 3.270 & 31.0 & 1.427 & 25.9 & 237 & 8.5 & 4.934 & 26.2 \\
\hline Cq. venezuelensis & 2.309 & 21.9 & 260 & 4.8 & 191 & 6.9 & 2.760 & 14.6 \\
\hline Cx. nigripalpus & 607 & 5.7 & 833 & 15.1 & 744 & 26.8 & 2.184 & 11.6 \\
\hline Cx. ribeirensis & 667 & 6.3 & 225 & 4.1 & 569 & 20.5 & 1.461 & 7.8 \\
\hline Ma. indubitans & 1.216 & 11.5 & 1.082 & 19.6 & 794 & 28.6 & 3.092 & 16.4 \\
\hline Total & 10.563 & 100.0 & 5.510 & 100.0 & 2.775 & 100.0 & 18.848 & 100.0 \\
\hline
\end{tabular}

- CDC - CDC automatic trap.

Shan - Shannon type trap.

In the collections by Shan-1 and Shan- 2 made in the residual woods, anopheline mosquitoes were virtually absent. The most common species collected were $C x$. nigripalpus, Ae. scapularis and $C x$. ribeirensis, which together accounted for nearly $80.0 \%$ of the total females caught. As shown in Fig. 4 a similar inversion was observed with regard to $C x$. nigripalpus and $C x$. ribeirensis. The same happens as regards this mosquito and Ae. scapularis, mainly in the dry and colder season, from April through October.

\section{Fonte (FT)}

The Shan-3 operating in the primitive forest collected 37,189 female mosquitoes, among which the most prevalent were as follows:
Species

Anopheles cruzii

An. bellator

Culex sacchettae

Psorophora ferox

Wyeomyia confusa

Aedes scapularis

Total

97.7

Clearly the anophelines of the Kerteszia subgenus were entirely dominant, and at least with the Shannon trap, An. cruzi + An. bellator were the most common mosquitoes occurring in the regional primitive forest. 
(A)
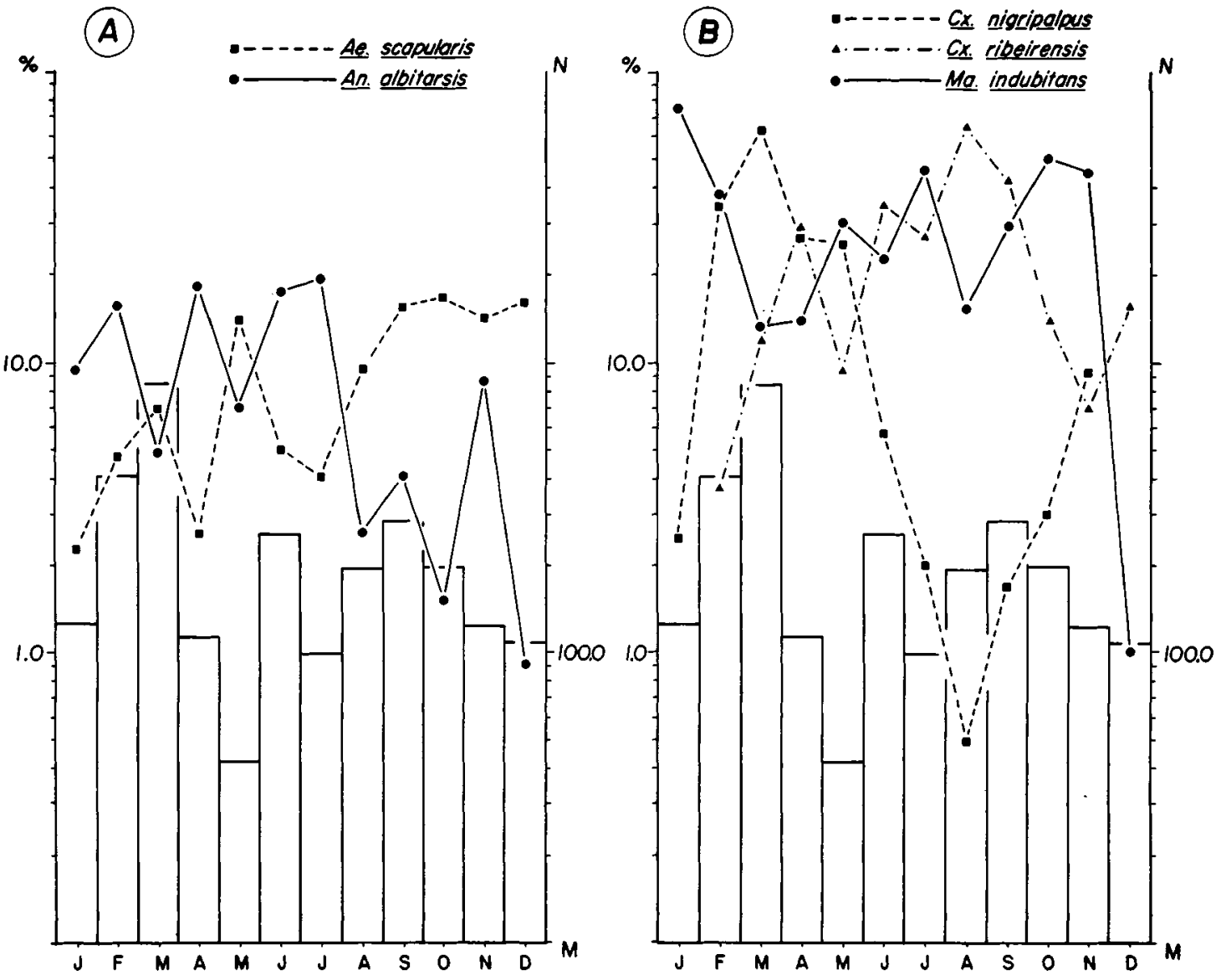

Figure 2. Distribution of female percentage rates in the monthly collections made at the residual pond (RP) of ES by the CDC. 3 trap, from January 1992 through January 1993. Bars represent the total numbers of females of species caught each month; A - Ae. scapularis and An. albitarsis; B - CX. nigripalpus, CX. ribeirensis and Ma. indubitans.

\section{Biodiversity}

A total of 105 identified species were obtained by the Shannon traps (Table 1). A comparison of the recorded biodiversities between the three habitats furnished the following indices, with a $5.0 \%$ confidence interval:
Site

Residual woods (RW)

Open land (IS)

Fonte (FT)
A quantitative difference was recorded with respect to the residual wood samples (Shan-1 plus Shan-2), that showed greater biodiversity than the other habitats. Of the 61 identified species collected by the automatic CDC traps at the ES (Table 2), the indices recorded were as follows:
Site

Rice paddy (IS)

Drainage trenches (IS)

Residual pond (RP)

Similarly, quantitative differences were found with regard to the residual pond samples (CDC-3), which revealed a higher degree of biodiversity than the other habitats.

Figures 5 to 9 present the main species percentages of the total number of females collected in the several habitats.

\section{Synanthropy}

As has already been mentioned, the three environments were compared by means of the synanthropic indices (s) for the species collected in these habitats. The results are presented in Table 4. 

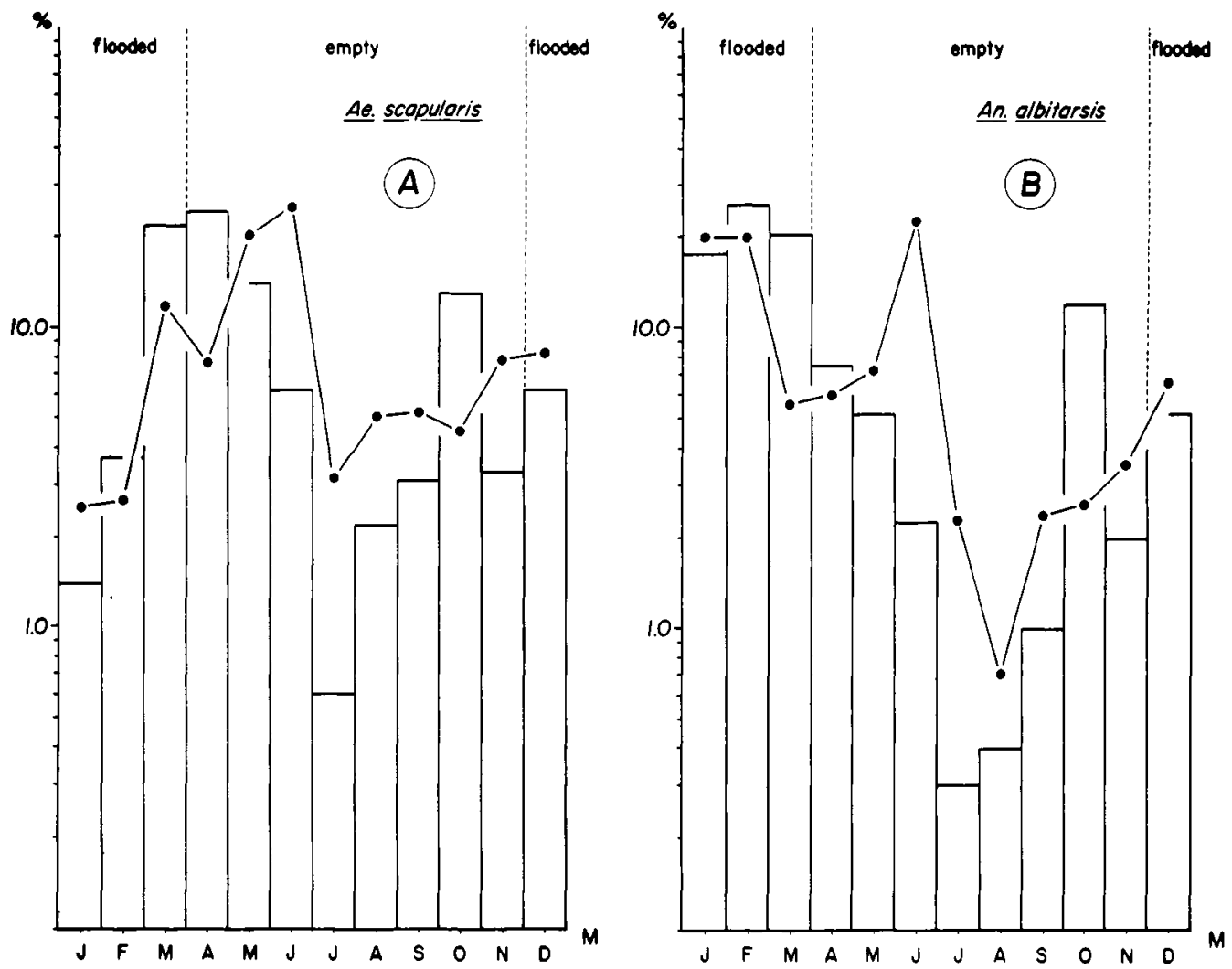

Figure 3. Monthly distribution of female Ae. scapularis (A) and An. albitarsis (B) caught on the ES open land by Shannon and CDC traps operating on the irrigation system (IS), from January 1992 through January 1993, according to the flooded or empty condition of the IS. Lines represent the results obtained with the Shan-E trap and bars those with the CDC-1 and CDC-2 traps.

Among the species presenting developing synanthropy, An.albitarsis and Ae. scapularis showed the highest degrees. The meaning of these indices is given in Fig. 10.

The synanthropic ratio (sr) yielded the overall value of 1.78 , suggesting that the ES habitat is suitable for a greater number of species than the FT. When the ES habitats are considered separately, the synanthropic ratios are as follows:

$$
\begin{aligned}
& \mathrm{sr}=\frac{\mathrm{IS}}{\mathrm{FT}}=0.72 \\
& \mathrm{sr}=\frac{\mathrm{RW}}{\mathrm{FT}}=1.05
\end{aligned}
$$

Thus, practically no differences were observed between the residual woods (RW) and the primitive forest (FT) environments as regards their mosquito biodiversities. Nevertheless, when the IS data are compared with those of the primitive environment, the former showed a lower degree of biodiversity, sug- gesting the existance of a selective role that favors the synanthropy of the above mentioned species.

\section{Discussion}

Data about immature mosquitoes from the same study area have already been published (Forattini et al. $\left.{ }^{8}, 1993\right)$. The work reported here concerns the adult, in an attempt to establish the relationships existing between them and the behavior of the immature stages in the IS. Obviously adult sampling does not, strictly speaking, represent the local breeding production. Despite this, it is sufficient to suggest the habitat to which mosquitoes are adapted for carrying out their activities after their appearance at the breeding sites.

The results obtained at the ES showed clearly that An. albitarsis was one of the species most favored by the IS, despite former observations at the same site, which did not suggest such a pattern (Forattini et al. ${ }^{6}, 1989$ ). The explanation is probably to be found in a more recent adaptation of this mosquito, or alternatively due to insufficient sampling. In any case, former observations 


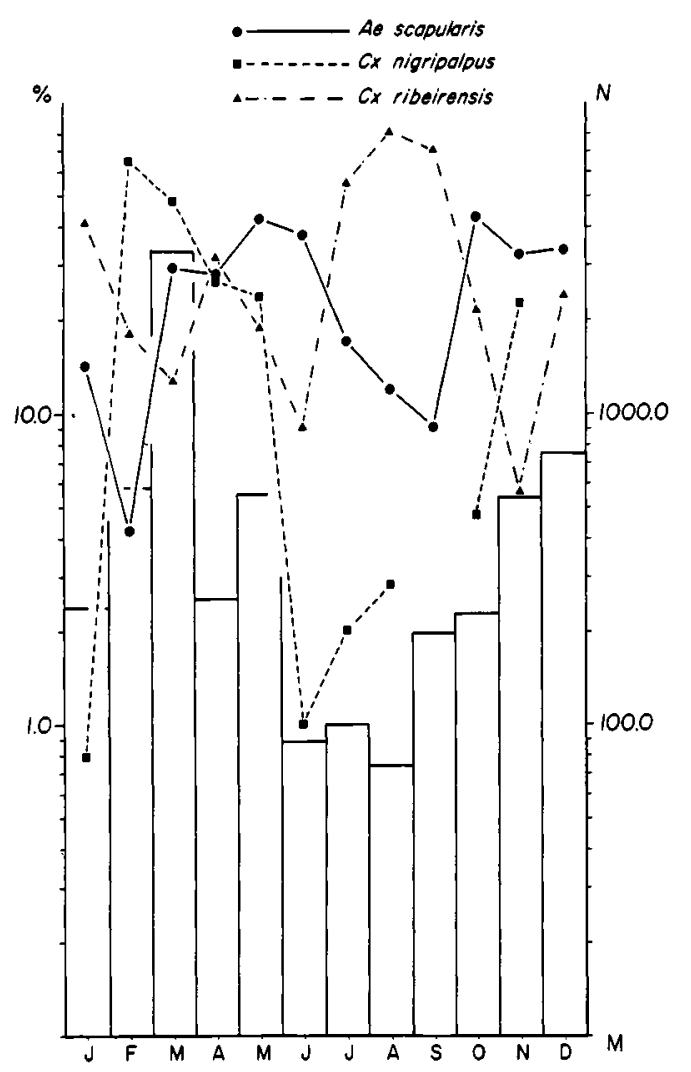

Figure 4. Distribution of $A e$. scapularis, $C x$. nigripalpus and $C x$. ribeirensis female percentage rates by the monthly collections made in the residual woods of ES by the Shan-1 and Shan-2 traps, from January 1992 through January 1993. Bars represent the total numbers of females of species caught each month.
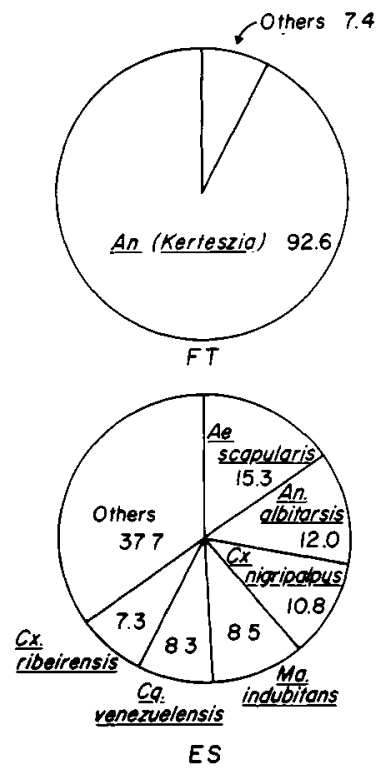

Figure 5. Diagram of the distribution of the principal species represented by the percentages of the total number of females caught at the Experimental Station (ES) and at the Fonte (FT).
An (Kerteszia)

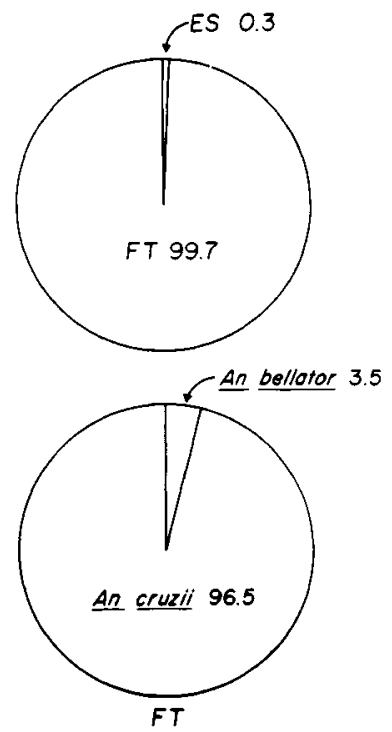

Figure 6. Dlagram of the Anopheles (Kerteszia) species represented as percentages of the total number of females caught. ES - Experimental Station FT - Fonte.

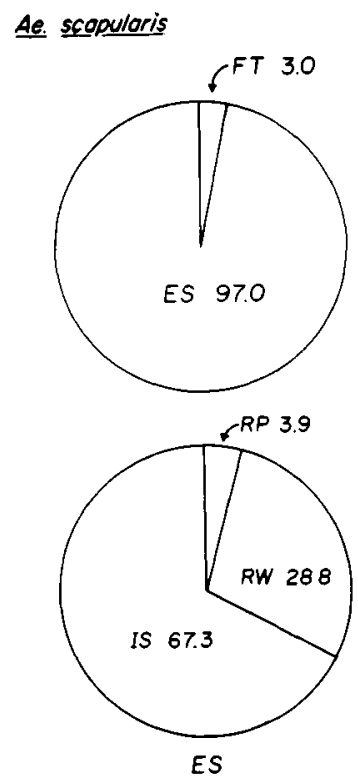

Figure 7. Diagram of the Aedes scapularis distribution as percentages of the total females caughtin the various habitats. ES. Experimental Station; FT. Fonte; IS- Irrigation system; RP. Residual pond; RW- Residual woods.

had also shown that Ae. scapularis and An. albitarsisare now the dominant species in the anthropic agricultural environment developed in that region. As was discovered with the immature stages, the adult production of these two species seems to alternate and is, to some degree, related to the flooding and emptying of the rice paddies. This inverse relationship was also observed 


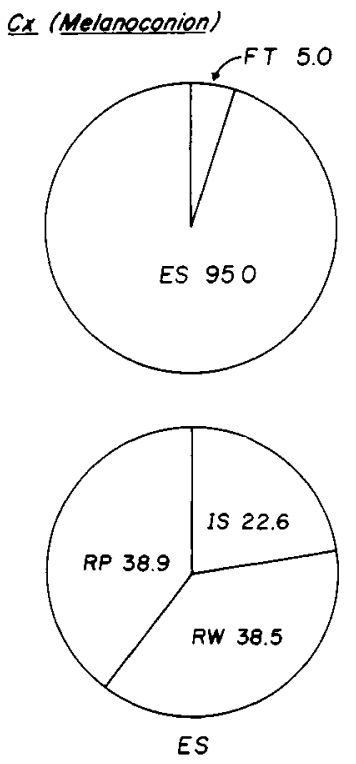

Figure 8. Diagram of the Culex (Melanoconion) species represented as percentages of the total females caught at the various habitats. ES- Experimental Station; FT. Fonte; IS. Irrigation system; RP- Residual pond; RW- Residual woods.
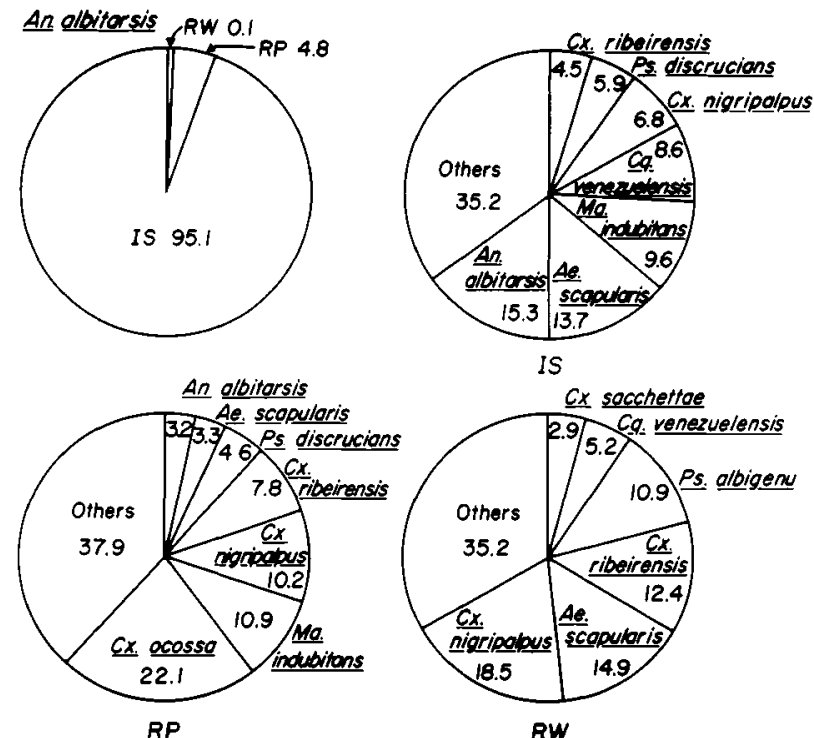

Figure 9. Diagram of the Anopneles albitarsis and the distribution of the main species identified at the Experimental Station (ES) habitats, represented as percentages of the total number of females caught. IS - Irrigation system; RP- Residual pond; RW- Residual woods.

Table 4. Nuorteva's synanthropic index estimated as percentages of female Culicidae of selected species collected in three environments *.

\begin{tabular}{lcccc}
\hline \multicolumn{1}{c}{ Species } & $\mathrm{a}(\%)$ & $\mathrm{b}(\%)$ & $\mathrm{c}(\%)$ & $\mathrm{s}$ \\
\hline An. albitarsis & 99.8 & 0.2 & 0.0 & +99.9 \\
An. cruzii & 0.03 & 0.29 & 99.7 & -82.2 \\
An. mediopunctatus & 5.0 & 46.0 & 49.0 & -21.0 \\
Ae. scapularis & 56.0 & 40.0 & 4.0 & +71.0 \\
Ae. serratus & 10.0 & 81.0 & 10.0 & +41.0 \\
Cx. nigripalpus & 21.0 & 78.0 & 2.0 & +58.0 \\
Cx. ribeirensis & 30.0 & 68.0 & 2.0 & +63.0 \\
Cx. sacchettae & 10.0 & 52.0 & 38.0 & - \\
Cq. venezuelensis & 79.0 & 21.0 & 0.1 & +89.6 \\
Mn. indubitans & 77.6 & 22.4 & 0.0 & +88.8 \\
Ps. albigenu & 8.2 & 88.6 & 3.3 & +49.2 \\
Wy. confusa & 0.0 & 43.6 & 56.4 & -34.7 \\
\hline
\end{tabular}

* a- Open land (Shan-E).

b- Residual woods (Shan-1 and Shan-2).

c- Primitive forest (Shan-3).

$s-$ Synanthropic index $\left(s=\frac{2 a+b-2 c}{2}\right)$

with the adult samples of other species such as $C x$. nigripalpus and $C x$. ribeirensis. The interpretation of this phenomenon is not clear and deserves the attention of further investigation. In adiction, several species of $C x$. (Melanoconion) appear to be favored by the anthropic man-made open land too.
When results obtained from the several ES habitats were compared, the occurrence of differences between them became evident. Thus, An. albitarsis was practically a non-existant mosquito in the residual woods (RW), its high prevalence at the irrigation system (IS) situated not much more than a kilometre away. 
The biodiversity was greater at ES than in the primitive environment of FT. This was mainly due to the RW influence that not only preserves some mosquito species even at low densities, but also represents a resting place for several others. Without doubt the irrigation system is favorable to the establishment and the emergence of An. albitarsis, even when the possibility that this population is a complex of several species is considered. In this sense it is a mechanism that has been related to malaria outbreaks as, for instance, was recently reported in Sri Lanka (Amerasinghe et al. ${ }^{1}$, 1991; Ramasamy et al..$^{15}$, 1992).

Several other mosquito species were favored by, and consequently established in, the IS. Among them Ae. scapularis, Cx. nigripalpus and many $C x$. (Melanoconion) such as $C x$. ribeirensis. This finding has already been reported in a general manner (Forattini et al. ${ }^{6}, 1989$ ). The increases of Coquillettidia and Mansonia species at the IS was

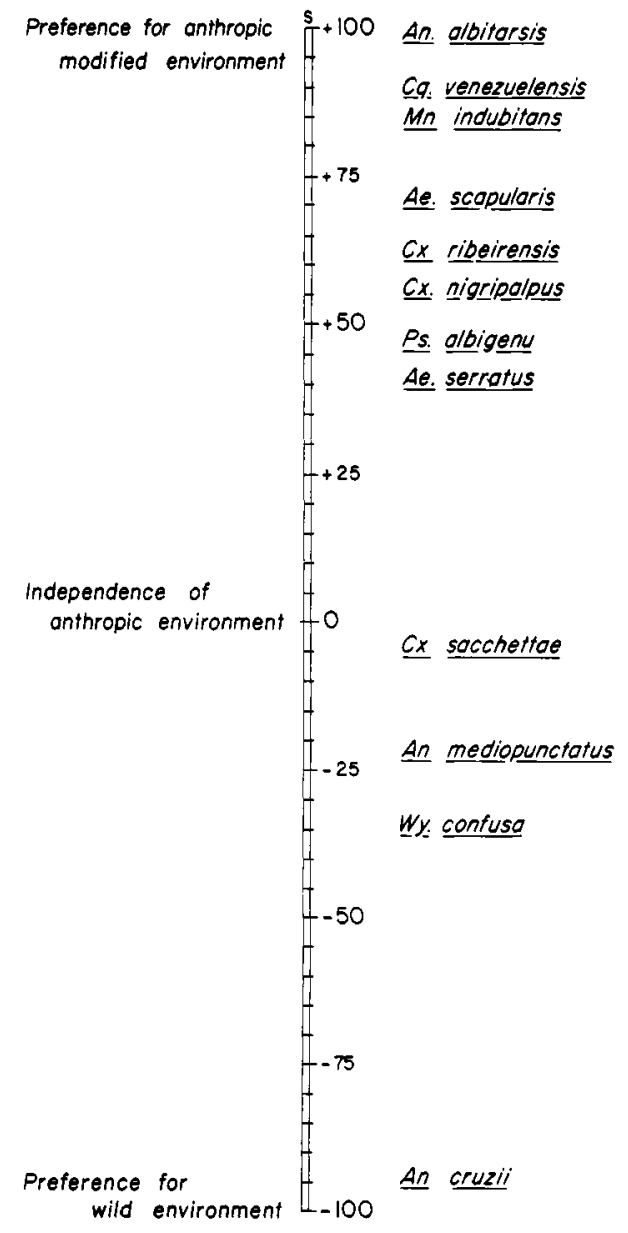

Figura 10. Representation of the different degrees of Culicidae synanthropic indices ( $\mathbf{s}$ ) in three habitats, according to the degree of anthropic modifications. regarded as unexpected in view of the fact that they are associated with aquatic plants in flooded environments.

It seems quite pertinent to conclude that $A n$. albitarsis, occurring at low densities in the natural environment of the forest, is an efficient colonizer of areas occupied by humans adopting the artificial irrigation technique for agricultural development. So this anopheline may be classified as an eusynanthrope, its adaptation being related to the human artificial environment in the region studied here. Furthermore, Ae. scapularis deserves attention as a hemisynanthropic population since its female synathropic ratio between open land (IS) and primitive forest (FT) collections (Table 1; $\mathrm{s} r=\mathrm{IS} / \mathrm{FT}$ ) was 13.0. Similar patterns were observed with $C x$. nigripalpus (8.4) and $C x$. (Melanoconion) species (2.7). For the latter subgenus, the value obtained with $C x$. ribeirensis was 19.6 and with $C x$. sacchettae 0.2 . Thus these two mosquitoes show apparently opposite behaviors as regards their synanthropic tendencies. Even within the residual woods (RW) they presented ratios sr=RW/FT of 43.7 10 the former and of 1.3 to the latter. So it seems appropriate to consider $C x$. ribeirensis as hemisynanthropic. As for $C x$. nigripalpus the $\mathrm{s} r=\mathrm{RW} /$ FT ratio was 30.8 , suggesting that it also constitutes a hemisynanthropic population. These observations confirm preliminary results obtained formerly in the same region (Forattini et al. $.^{5}, 1986$ ).

From the epidemiological point of view, the potential for malaria and arbovinus transmission may he increased. Such a probability arises from populations of settlers that may move into future development programs involving artificial irrigation in the region here studied.

Forattini,O.P.etal. Estudos sobre mosquitos (Diptera: Culicidae) e ambiente antrópico. 3 - Coleta de formas adultas no sistema de irrigação artificial para cultivo de arroz e emergência de Anopheles albitarsis na região sudeste do Brasil. Rev. Saúde Pública, 27:313-25, 1993. Relatam-se os resultados obtidos coma coleta regular de Culicidae adultos no período de janeiro de 1992 a janeiro de 1993, levadas a efeito no sistema artificialmente irrigado da Estação Experimental do Vale do Ribeira, SP Brasil. Evidenciou-se a emergência de Anopheles albitarsis como uma das espécies de mosquitos prevalentes no sistema irrigado. Esse aspecto, acrescido da sua prática ausência no meio natural primitivo ou mesmo nas matas residuais locais, levou à hipótese de se tratar de culicídeo eusinantrópico. As condiçôes artificiais apàrentemente favoreceram tambémAedes scapularis, Culer nigripalpus e $C x$. ribeirensis. A comparação das biodiversidades encontradas nos ambientes, antrópico e natural, não foi acentuada sob o ponto de vista quantitativo, mas o foi quanto à feição qualitativa. Aquelas espécies de maior prevalência mostraram incidências relativamente alternadas ao longo do período anual. A presença de $A n$. albitarsis foi mais prevalente nas épocas de inundação dos campos de arroz, enquanto $A e$. scapularis mostrou-se mais freqüente por ocasião do período inicial de esvaziamento dos arrozais irrigados. Tais resultados 
permitiram considerar Ae. scapularis, Cx. nigripalpus e $C x$. ribeirensis como culicídeos hemisinantrópicos. É de se admitir que a adoção da técnica de irrigação artificial para o desenvolvimento agrícola da região possa vir a favorecer o incremento de endemias veiculadas por mosquitos, como a malária.

Descritores: Mosquitos. Ecologia de vetores. Anopheles.

\section{References}

1. AMERASINGHE, F.P.; AMERASINGHE, P.H.; MALIK PEIRIS,J.S.; WIRTZ, R.A. Anopheline ecology and malaria infection during the irrigation development of an area of the Mahaweli project, Sti Lanka. Am. J. Trop. Med. Hyg., 45:226-35, 1991.

2. FISHER, R.A.; CORBET, A.S.; WILLIAMS, C.D. The relation between the number of species and the number of individuals in a random sample for an animal population. J. Anim. Ecol., 12:42-58, 1943.

3. FORATTINI, O.P.; GOMES, A. de C.; SANTOS, J.L.F.; GALATI, E.A.B.;RABELLO,E.X.; NATAL,D. Observações sobre atividade de mosquitos Culicidae em mata residual no Vale do Ribeira, São Paulo, Brasil. Rev. Saúde Pública, 15:557-86, 1981.

4. FORATTINI, O.P.; GOMES, A de C.; NATAL, D.; SANTOS, J.L.F. Observações sobre atividade de mosquitos Culicidae em mata primitiva da encosta no Vale do Ribeira, São Paulo, Brasil. Rev. Saúde Pública, 20:1-20, 1986.

5. FORATTINI, O.P.; GOMES, A. de C.; NATAL, D.; SANTOS, J.L.F. Observações sobre atividade de mosquitos Culicidae em matas primitivas da planície e perfis epidemiológicos de vários ambientes no Vale do Ribeira, São Paulo, Brasil. Rev. Salíde Pública, 20:178-203,1986.

6. FORATTINI, O.P.; GOMES, A. de C.; KAKITANI, I. Observaçōes sobre mosquitos Culicidae adultos em cultivo irrigado de arroz no Vale do Ribeira, Estado de São Paulo, Brasil. Rev. Saúde Pública, 23:307-12, 1989.

7. FORATTINI, O.P.; KAKITANI, I; MASSAD, E.; GOMES, A. de C. Studies on mosquitoes (Diptera: Culicidae) and anthropicenvironment. 1-Parity of blood seeking Anopheles (Kerteszia) in south-eastem Brazil. Rev. Saúde Pública, 27:1-8, 1993.

8. FORATTINI,O.P.; KAKITANI,I.; MASSAD,E.; MARUCCI, D. Studies on mosquitoes (Diptera: Culicidae) and anthropic environment. 2 -Immature stages survey at the rice irrigation system in the Ribeira Valley, São Paulo State, Brazil. Rev. Saúde Pública, 27: 227-36, 1993.

9. GIGLIOLI, G. Ecological change as a factor in renewed malaria transmission in an eradicated area. Bull. World Health Organ., 29:131-45, 1963.

10. INSTITUTOOCEANOGRÁFICO (USP). Bolm. climatol. Inst. Oceanogr., S.Paulo, (6):1-6, 1989.

11. LACEY, L.A. \& LACEY, C.M. The medical importance of riceland mosquitoes and their control using altematives to chemical insecticides. J. Am. Mosq. Control Ass. (Suppl. 2):1-93, 1990.

12. MCINTYRE, L. Jari: a massive technology transplant takes root in the Amazon jungle. Ntl. Geogr. Mag., 157:693-711, 1980.

13. NUORTEVA,P.Synanthropy of blowflies (Dipt., Calliphoridae) in Finland. Ann. Entomol. Fenn., 29:1-49, 1963.

14. POVOLNY, D. Synanthropy. In: Greenberg, B., ed. Flies and disease, Princeton, Princeton Univ. Press, 1971. v.1.

15. RAMASAMY, R.; DE ALWIS, R.; WIJESUNDERE, A.; RAMASAMY,M.S.Malaria transmission at a new irrigation project in Sri Lanka: the emergence of Anopheles annularis as a majorvector. Am.J.Trop.Med.Hyg., 47:547-53, 1992.

16. REINERT, J.F. Mosquito generic and subgeneric abbreviations (Diptera: Culicidae). Mosq. Syst., 7:105-10, 1975.

17. REINERT, J.F. Abbreviations for mosquito generic and subgeneric taxa established since 1975 (Diptera:Culicidae). Mosq. Syst., 14:124-6, 1982.

18. ROBERT JR., L.L. \& OLSON, J.K. Temporal abundance and percent insemination of newly-emerged adult female Psorophora columbiae near the larval habit. J. Am. Mosq. Control Ass., 2:485-89, 1986.

Recebido para publicação em 7.7 .93 Aprovado para publicaçâo em 23.9 .93 